\title{
Large B-Cell Lymphoma with IRF4 Rearrangement
}

National Cancer Institute

\section{Source}

National Cancer Institute. Large B-Cell Lymphoma with IRF4 Rearrangement. NCI

Thesaurus. Code C133494.

\begin{abstract}
A large B-cell lymphoma typically affecting the Waldeyer ring and/or cervical lymph nodes. It occurs most commonly in children and young adults and is low stage. It is characterized by a follicular, follicular and diffuse, or pure diffuse growth pattern resembling follicular lymphoma grade 3B or a diffuse large B-cell lymphoma. Most cases have IG/IRF4 rearrangements. BCL2 rearrangements are not present. Some cases that belong in this category lack an IRF4 rearrangement but have strong IRF4/MUM1 expression. This lymphoma is more aggressive than pediatric-type follicular lymphomas.
\end{abstract}

